\title{
CONSTRUCTION AND PARTIAL VALIDATION OF AN ANIMAL USE INVENTORY
}

\author{
Donald I. Templer, Lynette Bassman \\ Alliant International University, Fresno, CA, USA \\ E-mail: donaldtempler@sbcglobal.net \\ Christine Szostak \\ Ohio State University, Columbus, OH, USA \\ E-mail: SZOSTAK.1@osu.edu \\ Rhoda Myra Graces-Bacsal \\ Nanyang Technological University, Singapore \\ E-mail: Rhoda.bacsal@nie.edu.sg \\ Hiroko Arikawa \\ E-mail: hirokoar@gmail.com \\ Anne Petrovich \\ California State University, Fresno, USA \\ E-mail: apetrovich@csufresno.edu
}

Forest Institute of Professional Psychology, Springfield, MO, USA

\begin{abstract}
A 78-item Animal Use Inventory was constructed. Previous animal attitude scales have centered on affection, bonding, companion animal ownership, animal-human continuity, and general attitudes toward animals, but not use of animals. The present inventory has six scales: Sports and Entertainment, Hunting, Working and Service, Research, Fur, and Loving and Affection. Men scored higher on the Hunting, Research, Entertainment, and Service scales. National Rifle Association members scored higher than animal protection society members on the Hunting and Fur scales. In general, the scales correlated positively with each other but negatively with the Loving and Affection scale. Nevertheless, caution was urged because of the unimpressive Cronbach's alphas on some of the scales. Further development is recommended.
\end{abstract}

Key words: animal use, ethnicity, gender, scales, hunting, companionship, work, food.

\section{Introduction}

Templer and Arikawa (2011) reviewed eight attitude-toward-animal scales. The Pet Attitude Scale (Templer, Salter, Dickey, Baldwin, \& Veleber, 1981), the Censhare Pet Attachment Survey (Holcomb, Williams, \& Richards, 1988), the Lexington Attachment to Pets Scale (Johnson, Garrity, \& Stallone, 1995), and the Pet Relationship Scale (Lago, Kafer, Delaney, \& Connell, 1988) assess general companion animal attitudes and bonding with companion animals. The Companion Animal Bonding Scale (Poresky, Hendrix, Mosier, \& Samuelson, 1988) assesses bonding with companion animals. The Miller-Rado Commitment to Pets Scale (Stats, Miller, Carnot, Rado, \& Turnes, 1996) assesses companion animal responsibility and burden. The Animal-Human Continuity Scale (Templer, 
Connelly, Bassman, \& Hart, 2006) measures the degree to which the respondent perceives animals and humans as similar vs. different. There appears to be, however, no animal attitude instrument that is devoted primarily to attitudes toward uses that people have for animals. The construction of such is the purpose of the present research. It was originally planned that the Animal Use Inventory would have seven scales: Food, Sport and Entertainment, Hunting, Work and Service, Research, Fur, and Loving. It was anticipated that the scales could be used together or separately.

There are vast individual differences and group differences with respect to animal use and attitudes toward the various uses of animals. The Muslim, Jewish, Sikh, and Seventh Day Adventist religions forbid the eating of pork. The Hindu religion forbids the eating of beef. Also, many persons are vegetarians or vegans for health reasons. The eating of dogs is fairly common in East Asian and Southeast Asian countries such as Korea (WuDunn, 1997) and the Philippines (Griffith, Wolch, \& Lassiter, 2002). Chicken fighting is common in Latin American and Asian cultures. Some Southeast Asians fight fish. The fighting of dogs is carried out in various countries, including the United States where it is illegal. Bull fighting is a popular sport in Spain and Latin American countries. Horse racing is a popular sport and, in fact, is a multimillion-dollar industry in the United States with both legal and illegal betting. The racing of dogs (greyhounds and whippets) is less popular. Dogs are used to guard people and property and livestock. They are also used to herd livestock and for hunting. Dogs are used by persons with special needs such as the hearing and mobility impaired and elderly persons. Fishman (2003) reviewed the history of guide dogs for the visually impaired from the use of small dogs in Pompeii prior to the eruption of Vesuvius to the use of large breeds in the last 100 years. Hooker, Freeman, and Stewart (2002) reviewed pet therapy and the related topic of the cardiovascular benefits of companion animals. Horses, donkeys, mules, llamas, oxen, water buffalo, and elephants are used as beasts of burden. In the $19^{\text {th }}$ century, rottweilers were used in Germany to pull milk carts. There are millions of companion animal dogs and cats in the United States. It should be borne in mind, however, that all persons in the world do not have as positive an attitude toward companion animals as persons in countries with populations that are primarily of European origin. The regarding of animals as family members is much less common in African and Muslim countries. Muslims tend to have a negative attitude toward having dogs, which are regarded as "dirty," as companion animals. There are millions of fishermen and hunters in the United States. Quite a few of them have trophies on display. The use of animals for education and research has been controversial in both psychology departments (Hull, 1996; Cunningham, 2002; Baldwin, 2003) and medical schools (Council of Scientific Affairs, American Medical Association, 1991).

\section{Methodology of Research}

\section{Selection of Items}

The authors devised preliminary items for each of the seven scales. There were 14 tentative items in the Animals for Food category; 12 in the Animals for Sports and Entertainment category; 9 in the Animals for Hunting category; 16 in the Working and Service Animals category; 14 in the Animals for Research category; 9 in the Animals for Fur, Clothing, and Decoration category; and 11 items in the Animals for Affection and Loving category. The 85 items were administered to Alliant International University students and employees on the Fresno campus.

The questionnaire was placed in the boxes of approximately 237 graduate students and 42 employees (faculty, staff, and administrators). Twenty-four percent of the 279 were returned. The low rate of return was probably a function of the distribution having been in the week before final exam week. There were 15 male (23.8\%) and 48 female (76.2\%) participants. They ranged in age from 22 to 70 with a mean of 33.89 and a standard deviation of 11.26 .

\section{Comparison of Different Groups on the Animal Use Inventory}

Validation of the Animal Use Inventory was carried out by two comparisons of groups that would be expected to differ on the instrument. One of these consisted of comparing the means of Filipino and American college students on the 7 scales of the Animal Use Inventory. In addition, a special 
comparison was made on the item pertaining to eating dogs. Filipino college students tend to have above-average socioeconomic status. It is primarily the poor Filipinos who eat dog. Nevertheless, it was predicted that the Filipino college students would be more accepting of the concept of eating dog than American college students. The other comparison was between members of the National Rifle Association (NRA) and members of two animal welfare organizations. It was anticipated that the two groups would differ, especially on the Hunting scale.

The 64 Filipino college students, 41 males and 23 females, were in psychology undergraduate classes at Kalayaan College in the Philippines. They ranged in age from 17 to 25 with a mean of 19.39 years and a standard deviation of 1.86 years. The 166 American college students, 79 males and 87 females, were in psychology undergraduate classes in three different colleges in the San Joaquin Valley of California. They ranged in age from 17 to 50 years with a mean of 22.29 and a standard deviation of 5.51. Both the Filipino and the American students were administered the Animal Use Inventory in their classrooms.

The 18 National Rifle Association (NRA) members, 11 males and seven females, ranged in age from 17 to 50 years with a mean of 21.29 years and standard deviation of 5.51. The 37 animal welfare participants, five males and 32 females, were obtained from two affiliated organizations in the Fresno, California, area - the California Feline Association and the Valley Animal Shelter. They ranged in age from 31 to 68 years with a mean of 52.33 and standard deviation of 9.91. All organizational members were administered the Animal Use Inventory in their regular meetings.

\section{Results of Research}

In each of the seven categories, item-total score correlations were computed for that category with the Alliant students and employees. The criterion of acceptance for the items was that the correlations be significant at the .001 level. Seventy-eight items met the criterion for acceptance. Table 1 contains the 14 items in Animals for Food category; 10 in the Animals for Sports and Entertainment category; 8 in the Animals for Hunting category; 14 in the Working and Service Animals category; 12 in the Animals for Research category; 9 in the Animals for Fur, Clothing, and Decoration category; and 11 items in the Animals for Affection and Loving category. On each scale one point is scored for every item answered in the keyed direction.

\section{Table 1. The item number and category of the $\mathbf{7 8}$ Animal Use Inventory items.}

\begin{tabular}{|c|c|c|c|}
\hline $\begin{array}{l}\text { Item } \\
\text { No. }\end{array}$ & $\begin{array}{l}\text { Direction } \\
\text { Keyed* }\end{array}$ & Category & Item \\
\hline 1 & + & Loving & It is nice to have turtles as pets. \\
\hline 2 & + & Service & Animals pulling plows is OK. \\
\hline 3 & + & Service & It is OK to use animals as a form of transportation. \\
\hline 4 & + & Food & It is OK to eat meat if you use the whole animal and are not wasteful. \\
\hline 5 & + & Research & $\begin{array}{l}\text { I think it is OK to use primates, such as monkeys and chimpanzees, for } \\
\text { research. }\end{array}$ \\
\hline 6 & + & Loving & Pets should receive the best health care possible. \\
\hline 7 & + & Food & It's OK to eat shellfish. \\
\hline 8 & + & Research & Animals should not be used in research if they will be killed. \\
\hline 9 & + & Fur & I think it is OK to have fish mounted on the wall. \\
\hline 10 & + & Service & It's a good idea to have a guard dog to protect one's property. \\
\hline 11 & + & Entertainment & $\begin{array}{l}\text { It is OK to keep ocean animals, like dolphins and whales, captive for } \\
\text { performing. }\end{array}$ \\
\hline 12 & - & Food & People should not eat horses. \\
\hline 13 & + & Service & It is good to use dogs for search and rescue. \\
\hline 14 & + & Entertainment & Bullfighting is OK. \\
\hline
\end{tabular}




\begin{tabular}{|c|c|c|c|}
\hline $\begin{array}{l}\text { Item } \\
\text { No. }\end{array}$ & $\begin{array}{l}\text { Direction } \\
\text { Keyed* }\end{array}$ & Category & Item \\
\hline 15 & - & Food & Birds should not be eaten. \\
\hline 16 & - & Fur & It is wrong to have furnishings, such as rugs, made from animal skills. \\
\hline 17 & + & Research & Animal research is necessary. \\
\hline 18 & + & Entertainment & The fighting of roosters is good for entertainment. \\
\hline 19 & + & Food & It's OK to eat eggs. \\
\hline 20 & + & Fur & It's OK to wear fur. \\
\hline 21 & + & Loving & Fish make good pets. \\
\hline 22 & + & Loving & It is OK to have an animal sleep in one's bed. \\
\hline 23 & + & Entertainment & It is OK to have animals pull carriages for fun and entertainment. \\
\hline 24 & + & Hunting & I think it is OK to hunt an animal if there are too many of them. \\
\hline 25 & - & Food & People should not eat dogs. \\
\hline 26 & + & Hunting & It is OK to hunt rabbits. \\
\hline 27 & + & Service & It is OK to have animals for personal protection. \\
\hline 28 & + & Hunting & It is OK to hunt lions and tigers. \\
\hline 29 & & Loving & I would like a pet in my home. \\
\hline 30 & + & Fur & It think it is OK to have animal heads mounted on the wall. \\
\hline 31 & + & Service & It is OK to use animals in a war effort. \\
\hline 32 & + & Hunting & It is OK to shoot wolves and foxes. \\
\hline 33 & - & Food & People should not eat rabbit. \\
\hline 34 & + & Research & $\begin{array}{l}\text { Using animals for testing beauty products, such as shampoo and make- } \\
\text { up, is okay. }\end{array}$ \\
\hline 35 & + & Loving & Cats are loving animals. \\
\hline 36 & + & Research & I think it is OK to use rats and mice for research. \\
\hline 37 & + & Service & It is good to have a dog to herd animals. \\
\hline 38 & + & Entertainment & Having animals in circuses and carnivals is OK. \\
\hline 39 & - & Food & People should not eat pork. \\
\hline 40 & + & Service & Having animals carry things is $\mathrm{OK}$. \\
\hline 41 & + & Research & I think it is OK to use dogs for research. \\
\hline 42 & + & Fur & $\begin{array}{l}\text { It is OK to use ivory, such as from elephant's tusks, for jewelry and } \\
\text { carvings. }\end{array}$ \\
\hline 43 & + & Research & Using animals for testing household cleaners is OK. \\
\hline 44 & + & Service & It is good to have dogs as an aid to the hearing impaired/deaf. \\
\hline 45 & + & Hunt & It is OK to fish. \\
\hline 46 & - & Food & People should not at cats. \\
\hline 47 & - & Fur & One should not wear clothing made of leather. \\
\hline 48 & - & Fur & I am against trapping animals for their fur. \\
\hline 49 & - & Entertainment & It is cruel to have animals in the zoo. \\
\hline 50 & - & Food & I do not believe in eating fish. \\
\hline 51 & + & Loving & Snakes make good pets. \\
\hline 52 & + & Research & Animal research should be done if it will save animal lives. \\
\hline 53 & + & Service & It is good to have dogs as a guide for those who are blind. \\
\hline 54 & + & Entertainment & It's all right to race animals. \\
\hline 55 & - & Food & People should not eat monkeys. \\
\hline 56 & + & Service & It is OK to have animals pull heavy loads. \\
\hline
\end{tabular}




\begin{tabular}{|c|c|c|c|}
\hline $\begin{array}{l}\text { Item } \\
\text { No. }\end{array}$ & $\begin{array}{c}\text { Direction } \\
\text { Keyed* }\end{array}$ & Category & Item \\
\hline 57 & - & Research & Animals should not be used in research if they will experience pain. \\
\hline 58 & + & Loving & A dog is a person's best friend. \\
\hline 59 & + & Service & It is good to use dogs for finding drugs and explosives. \\
\hline 60 & + & Entertainment & Dog shows are OK. \\
\hline 61 & + & Hunting & Duck hunting is good. \\
\hline 62 & + & Service & It is good for police officers to have dogs to confront criminals. \\
\hline 63 & - & Fur & It is wrong to raise sheep for their wool. \\
\hline 64 & + & Loving & Pets should be treated as members of the family. \\
\hline 65 & + & Hunting & It is OK to hunt elephants. \\
\hline 66 & - & Food & People should not eat veal (baby cows raised in crates). \\
\hline 67 & + & Entertainment & Fishing is OK if it is catch and release. \\
\hline 68 & + & Service & It is good to use animals to pull people over ice or snow. \\
\hline 69 & + & Research & It is OK to use animals for organ transplants. \\
\hline 70 & + & Loving & Birds are great pets. \\
\hline 71 & + & Loving & House pets add happiness to people's lives. \\
\hline 72 & + & Hunting & It is OK to hunt deer. \\
\hline 73 & + & Research & Animal research is OK it if will benefit people's lives. \\
\hline 74 & - & Fur & There should be laws prohibiting the raising of animals for fur. \\
\hline 75 & - & Food & I do not believe in eating dairy products. \\
\hline 76 & + & Research & I think it is OK to genetically alter animals \\
\hline 77 & + & Entertainment & It is OK to use animals in rodeos. \\
\hline 78 & + & Food & It's OK to eat meat if one is going to starve otherwise. \\
\hline
\end{tabular}

+ means score the number circled.

- means reverse the scoring.

Table 2 presents the means and standard deviations for the seven AUI scales for the Filipino and American college students. It is apparent that the American college students scored significantly higher on the Hunting and Fur scales and that the Filipinos scored significantly higher on the Research scale. It should be further noted that the Filipinos were higher $(\mathrm{p}=0.053)$ on the Food Scale and that the Americans $(p=0.056)$ were higher on the Entertainment scale.

Table 2. AUI scale means and standard deviations for Filipino and American college students.

\begin{tabular}{|c|c|c|c|c|c|c|}
\hline \multirow[b]{2}{*}{ Scales } & \multicolumn{2}{|c|}{ Filipino } & \multicolumn{2}{|c|}{ American } & \multirow[b]{2}{*}{$\mathrm{F}$} & \multirow[b]{2}{*}{$p$} \\
\hline & M & $\mathrm{SD}$ & $M$ & $\mathrm{SD}$ & & \\
\hline Loving & 56.5 & 8.9 & 57.0 & 11.0 & 0.09 & 0.769 \\
\hline Food & 36.2 & 7.1 & 34.3 & 6.4 & 3.77 & 0.053 \\
\hline Service & 76.0 & 8.9 & 75.7 & 13.1 & .03 & 0.835 \\
\hline Research & 46.6 & 9.2 & 43.2 & 11.9 & 4.20 & 0.042 \\
\hline Entertainment & 36.4 & 8.5 & 39.1 & 10.1 & 3.70 & 0.056 \\
\hline Hunting & 25.1 & 7.8 & 28.6 & 11.8 & 4.87 & 0.028 \\
\hline Fur & 18.2 & 6.0 & 21.2 & 6.9 & 10.06 & 0.002 \\
\hline
\end{tabular}

The Filipino and American college students both tended to be opposed to eating dogs. A higher 
percentage of American students circled 7, the option of greatest agreement for question 25, "People should not eat dogs." Thirty-nine (60.94\%) of the Filipino participants and $128(75.74 \%)$ of the American participants chose that opinion, $\mathrm{x}^{2}(\mathrm{n}=230)=5.21, \mathrm{p}<0.05$.

Table 3 presents the means and standard deviations for the seven Animal Use Inventory scales for the NRA members and the animal protection society members. The protection society members had a significantly higher mean on the Loving scale. The NRA members had a significantly higher mean on the Service, Research, Entertainment, Hunting and Fur scales. It is noteworthy, although not surprising, that there was a difference of over three standard deviations on the Hunting scale. Because there was a disproportionate number of females in the animal welfare component group, analysis of covariance was performed with sex as the covariant. Significance was obtained on the Hunting scale, $F(2,53)=96.79, \mathrm{p}<0.001$ and the Fur scale, $\mathrm{F}(2,53)=25.26, \mathrm{p}<0.001$.

Table 3. Scale means and standard deviations for NRA and protection society.

\begin{tabular}{|c|c|c|c|c|c|c|}
\hline \multirow[b]{2}{*}{ Scales } & \multicolumn{2}{|c|}{ Filipino } & \multicolumn{2}{|c|}{ American } & \multirow[b]{2}{*}{$F$} & \multirow[b]{2}{*}{$p$} \\
\hline & $M$ & SD & M & SD & & \\
\hline Loving & 57.7 & 7.6 & 63.2 & 5.3 & 7.44 & 0.009 \\
\hline Food & 35.6 & 4.3 & 39.1 & 6.1 & 2.44 & 0.124 \\
\hline Service & 82.4 & 6.0 & 72.8 & 14.3 & 7.91 & 0.007 \\
\hline Research & 40.4 & 1.4 & 31.7 & 14.0 & 5.44 & 0.023 \\
\hline Entertainment & 35.6 & 6.7 & 29.8 & 7.6 & 7.72 & 0.008 \\
\hline Hunting & 47.9 & 7.6 & 19.9 & 8.9 & 134.87 & 0.001 \\
\hline Fur & 22.8 & 7.3 & 12.6 & 5.6 & 37.16 & 0.001 \\
\hline
\end{tabular}

Statistical analyses using all 354 participants are as follows: the Cronbach's alphas for the seven scales, in descending order, 0.88 for the Hunting scale, 0.82 for the Working and Service Animals scale, 0.68 for the Affection and Loving scale, 0.65 for the Sport and Entertainment Scale, 0.59 for the Fur, Clothing, and Decoration scale, and 0.46 for the Food scale.

Table 4 displays the product-moment correlation coefficients of the Animal Use Inventory scales with sex and age for all 354 participants. It is apparent that males are more favorably disposed to using animals for human benefit than are females. Although age is minimally related to the Animal Use Inventory, younger persons are more favorably disposed to using animals for research and for entertainment.

Table 4. Correlations of AUI scale with age and sex for all 564 participants (r).

\begin{tabular}{lll}
\hline Scales & Age & Sex \\
\hline Loving & 0.04 & -0.02 \\
Food & -0.04 & -0.09 \\
Service & -0.12 & $-0.31^{\text {** }}$ \\
Research & $-0.24^{* *}$ & $-0.32^{\star *}$ \\
Entertainment & $0.16^{*}$ & $-0.33^{\star *}$ \\
Hunting & -0.07 & $-0.20^{* *}$ \\
Fur & -0.08 & -0.09 \\
\hline
\end{tabular}

${ }^{a} 1=$ males $; 2=$ females $;{ }^{*}<0.005 ;{ }^{* *}<0.001$

Table 5 contains the product-moment correlation coefficients between the seven Animal Use Inventory scales. Perhaps the more omnibus generalization is that six of the scales tend to correlate positively with each other and that the Animals for Affection and Loving scale tends to have negative or insignificant correlations with the other scales. 
Table 5. Inter-correlations of the seven Animal Use Inventory scales for all 354 participants.

\begin{tabular}{|c|c|c|c|c|c|c|c|}
\hline Scales & Food & Entertainment & Hunting & Service & Research & Fur & Loving \\
\hline Animals for Food & & 0.08 & $0.23^{* *}$ & 0.00 & $0.25^{\star *}$ & $0.31^{* *}$ & $-0.25^{\star *}$ \\
\hline $\begin{array}{l}\text { Animals for Sport and } \\
\text { Entertainment }\end{array}$ & & & $0.48^{* *}$ & $0.46^{* *}$ & $0.56^{* *}$ & $0.46^{* *}$ & .03 \\
\hline Animals for Hunting & & & & $0.14^{*}$ & $0.39^{* *}$ & $0.69^{\star *}$ & $-0.21^{\star *}$ \\
\hline $\begin{array}{l}\text { Working and Service } \\
\text { Animals }\end{array}$ & & & & & & -0.06 & $0.30^{* *}$ \\
\hline Animals for Research & & & & & & $0.35^{* *}$ & -0.09 \\
\hline $\begin{array}{l}\text { Animals for Fur, } \\
\text { Clothing, and Decoration }\end{array}$ & & & & & & & $-0.25^{\star *}$ \\
\hline
\end{tabular}

\section{Discussion}

The psychometric properties of the Animal Use Inventory can probably be best described as generally adequate. It had been decided to limit the number of items for the scale so that the total number would not be burdensome. Thus, there was a tradeoff which yielded unimpressive Cronbach's alphas for some of the scales. Nevertheless, the group differences, the sex differences, and the scale intercorrelations are supportive of validity.

The Hunting scale has good psychometric properties. It has a Cronbach's alpha of 0.88 . Its correlation of 0.69 with Fur, the highest correlation in the matrix, seems reasonable since both involve the killing of animals. Other meaningful significant correlations are 0.23 with Food, 0.48 with Sport, and -0.21 with Loving. More importantly, members of the National Rifle Association scored higher than members of animal welfare organizations and males scored higher than females

The Working and Service scale has good psychometric properties with a Cronbach's alpha of 0.82. Its highest correlation is .48 with Sport and Entertainment. Both scales assess the animals working to meet the needs of humans. Males are higher on both of these scales.

The Loving scale has a Cronbach's alpha of 0.68 . Its correlating negatively with Food and Hunting and Fur is consistent with common sense since these three scales pertain to the killing of animals. The fact that American college students scored higher than Filipino college students is consistent with persons of European origin having more favorable attitudes toward companion animals.

The Sport and Entertainment scale has a Cronbach's alpha of 0.65. Its correlations of 0.48 with Hunting, 0.46 with Service, 0.56 with Research, and 0.46 with Fur are reasonable since all of these scales involve using animals to fulfill the needs of humans. There was a meaningful Entertainment scale.

The Fur scale has a Cronbach's alpha of 0.59. Its highest correlation of 0.69 with Hunting was predictable since both involve the killing of animals. Its positive correlation with Food and Sport and Research also made sense. Filipino students scored lower on the Fur scale than American students. The Philippines is a tropical country where the wearing of very warm clothing is not necessary.

The weakest scale with respect to internal consistency is the Food scale, with a Cronbach's alpha of only 0.46 . An inspection of the items reveals considerable heterogeneity with the inclusion of eating fish, eating animals ordinarily regarded as companion animals by Americans, religious prohibitions, eating non-human primates, eating veal, and consuming dairy products. It was decided not to include the Food scale in the Animal Use Inventory. 


\section{Conclusion}

All of the intended scales have some degree of validity with respect to group differences and correlations. The internal consistency is greatest in the Hunting and the Working and Service scales. Discriminant validity of the individual scales is evidenced by no excessive high correlation between scales. The Food scale appears to not measure a sufficiently unidimensional entity. Either more work on this scale or more than one food scales appears to be needed.

\section{References}

Al-Fayez, F., Awadalle, A., Templer, D. I., \& Arikawa, H. (2003). Pet attitude and its family pattern in Kuwait. Society and Animals, 11, 17-28.

Baldwin, E. (1993). The case for animal research in psychology. Teaching of Psychology, 49 (1), 121-131.

Council of Scientific Affairs, American Medical Association (1991). Use of animals in medical education. Journal of the American Medical Association, 266 (6), 836-837.

Cunningham, P. F. (2003). Animal use, student choice, and non-animal alternatives at "America's best" undergraduate colleges. Teaching of Psychology, 30 (3), 288-296.

Fishman, G. A. (2003). When your eyes have a wet nose: The evolution of the use of guide dogs and establishing the seeing eye. Survey of Ophthalmology, 48 (4), 452-458.

Griffith, M., Wolch, J., \& Lassiter, U. (2002). Animal practices and the racialization of Filipinas in Los Angeles. Society \& Animals, 10 (3), 221-248.

Holcomb, R., Williams, R. C., \& Richards, P. S. (1988). The elements of attachment: Relationship to maintenance and intimacy. Journal of the Delta Society, 2, 28-34.

Holden, Constance. (1986). A pivotal year for lab animal welfare. Science, 232, 147-150.

Hooker, S. D., Freeman, H. L., \& Stewart, P. (2002). Pet therapy research: A historical review, Holistic Nursing Practice, 16 (5), 17-23.

Hull, D. B. (1996). Animal use in undergraduate psychology programs. Teaching of Psychology, 23 (3), 171-174.

Johnson, T. P., Garrity, T. F., \& Stallones, L. (1995). Psychometric evaluation of the Lexington Attachment to Pets Scale (LAPS). Anthrozoos, 5, 160-175.

Kellert, Stephen R. (1983). Historical trends in American animal use and perception. International Journal for the Study of Animal Problems, 4, 133-146.

Lago, D., Kafer, R., Delaney, M., \& Connell, C. (1988). Assessment of favorable attitudes towards pets: Development and preliminary validation of self-report pet relationship scales. Anthrozoos, 1, 240-284.

Poresky, R. H., Hendrix, C., Mosier, J. E., \& Samuelson, M. L. (1987). The companion animal bonding scale: Internal reliability and construct validity. Psychological Reports, 60, 743-746.

Poresky, R. H., Hendrix, C., Mosier, J. E., \& Samuelson, M. L. (1988). The companion animal semantic differential: Long and short form reliability and validity. Educational and Psychological Measurement, 48, 255-260.

Schenck, S. A., Templer, D. I., Peters, N., \& Schmidt, M. (1994). The genesis and correlates of attitudes toward pets. Anthrozoos, 7, 60-68.

Stats, S., Miller, D., Carnot, M. J., Rada, K., \& Turnes, J. (1996). The Miller-Rada Commitment to Pets Scale. Anthrozoos, 9 (2/3), 88-93.

Tannenbaum, J. (2001). The paradigm shift toward animal happiness: What is it, why is it happening, and what it portends for medical research. In E. F. Paul (Ed.), Why Animal Experimentation Matters: The Use of Animals in Medical Research. New Studies in Social Policy (pp. 93-130). New Brunswick, NJ: Transaction Publishers.

Templer, D. I., \& Arikawa, H. (2011). The Pet Attitude Scale. In C. Blazina, G. Boyraz, \& D. Shen-Miller (Eds.), The Psychology of the Human-Animal Bond (pp.335-359). New York, NY: Springer Science. 
Templer, D. I., Connelly, H., Bassman, L., \& Hart, J. (2006). Construction and validation of an animal-human continuity scale. Social Behavior and Personality, 34, 769-776.

Templer, D. I., Salter, C. A., Dickey, S., Baldwin, R., \& Veleber, D. M. (1981). The construction of a Pet Attitude Scale. Psychological Record, 31, 343-348.

WuDunn, S. (1997, January 2). Where a dog can be a pet, or a dining experience. New York Times, p. A4.

Advised by Serhiy Boltivets,
Grigory Kostyuk Psychological Institute of the Ukrainian National Academy of
Pedagogical Sciences, Ukraine

Received: September 30, 2013

Accepted: December 06, 2013

\begin{tabular}{|c|c|}
\hline Donald I. Templer & $\begin{array}{l}\text { Ph.D., Professor (Retired), Alliant International University, } 257 \text { West Los Altos, Fresno, } \\
\text { CA, USA } \\
\text { E-mail: donaldtempler@sbcglobal.net }\end{array}$ \\
\hline Lynette Bassman & $\begin{array}{l}\text { Ph.D., Associate Professor, Alliant International University, } 5130 \text { E. Clinton Avenue, } \\
\text { Fresno, California 93727, USA. }\end{array}$ \\
\hline Christine Szostak & $\begin{array}{l}\text { PhD., Graduate Researcher, Department of Psychology, Ohio State University, } \\
\text { Columbus, OH, USA. } \\
\text { E-mail: SZOSTAK.1@osu.edu }\end{array}$ \\
\hline Rhoda Myra Graces-Bacsal & $\begin{array}{l}\text { Assistant Professor, Department of Early Childhood \& Special Needs Education, } \\
\text { National Institute of Education, Nanyang Technological University, Singapore. } \\
\text { E-mail: Rhoda.bacsal@nie.edu.sg }\end{array}$ \\
\hline Hiroko Arikawa & $\begin{array}{l}\text { Lecturer, Forest Institute of Professional Psychology, Springfield, Missouri, MO, USA. } \\
\text { E-mail: hirokoar@gmail.com }\end{array}$ \\
\hline Anne Petrovich & $\begin{array}{l}\text { Ph.D., L.C.S.W., Prof. Emeritus, Department of Social Work Education, California State } \\
\text { University, Fresno, California 93727, USA. } \\
\text { E-mail: apetrovich@csufresno.edu }\end{array}$ \\
\hline
\end{tabular}

